\title{
Sima Qian as a Reader of Master Kong's Utterances
}

\author{
Bernhard Fuehrer
}

Based on selected passages in the Shiji 史記 (Records of the Scribe) $)^{1}$ this paper attempts to shed light on Sima Qian's 司馬遷 $(c .145-c .85$ BCE) readings of the utterances of Confucius in the wider context of the reception history of the Lunyu 論語 (Analects). It understands the records and interpretations transmitted in the Shiji as a widely overlooked early hermeneutical attempt to contextualise and clarify the meaning of statements made by Master Kong.

The earliest description of a textual body titled Lu Lunyu 鲁論語 as a compilation of the utterances of Kong Qiu 孔丘 (trad. 551-479), latinized as Confucius, by his disciples seems to date back to Liu Xiang 劉向 (79-8 BCE) who is quoted by He Yan 何晏 (190-249) at the very beginning of his preface ( $x u$ 序; dated 242) to the Lunyu jiie 論語集解. ${ }^{2}$ In his bibliographical chapter of the Han shu 漢書, Ban Gu 班固 (32-92) essentially follows a view attributed to Liu Xiang in referring to the title Lunyu 論語; however, he drops the regional specification reportedly made by Liu Xiang. ${ }^{3}$ Ban Gu's narrative also reports on the existence of three traditions of the Lunyu, the Lu Lun 鲁論 (20 pian) and the Qi Lun 齊 論 (22 pian), both in new script (jinwen 今文), and the Gu Lun 古論 (21 pian), a version written in ancient script (guwen 古文) and allegedly recovered from a wall in the former residence of Confucius during the reign of emperor Jing 景 (r. 157-141 BCE) of the Han. ${ }^{4}$

1 Technical note: Segmentation of the main text (jingwen 經文) of the Lunyu follows the Harvard-Yenching Index Series. Unless indicated otherwise references to Shiji and Han shu are to the Zhonghua editions. For Tang manuscript fragments I rely heavily on the International Dunhuang Project website of the British Library (London) which provides excellent digital reproductions of manuscript fragments and links to the holdings in other libraries such as the Bibliothèque Nationale (Paris), thereby offering convenient access to the manuscripts brought back to Europe by Paul Pelliot (1878-1945) and Marc Aurel Stein (1862-1943). Shortly prior to the conference in Prague, Esther Klein presented a paper entitled "Sima Qian's Kongzi and the Western Han Lunyu" at the conference "The Analects: A Western Han text?" held at Princeton in November 2011. I would like to thank Esther Klein for providing me with a draft of her paper in October 2012.

2 See Lunyu jijie, $x u$, 1a. The locus classicus on the Lunyu as a compilation by the master's followers is, of course, found in Han shu 30.1717. For a concise summary of the early history of the Lunyu see Cheng 1993. For the Lunyu as a text that took shape and was compiled into the received version during the Eastern Han period see Makeham 1996, Csikszentmihalyi 2002, Zhu Weizheng 2002, Csikszentmihalyi 2004, 28-32, and Makeham 2007, 103. For more recent contributions to this topic see Kern, Hunter and Weingarten 2015 (forthcoming).

3 See Han shu 30.1717.

4 See Han shu 36.1970 and Han shu 30.1706. In their attempts to reconstruct antiquity Qing scholars also attempted to re-establish the texts of these early versions from fragments and other secondary material. 
He Yan states that Kong Anguo 孔安國 (d. c. 100 BCE) and Ma Rong 馬融 (79-166) both compiled explanatory glosses on the Gu Lun, and that Zheng Xuan 鄭玄 (127-200) based himself primarily on the $L u$ Lun, collated it against the $Q i$ Lun and Gu Lun versions, and provided it with explanatory glosses. ${ }^{5}$

A first attempt to establish a standardised text of the Lunyu seems to date back to around $48 \mathrm{BCE}$ when Zhang $\mathrm{Yu}$ 張禹 (d. $5 \mathrm{BCE}$ ), an imperial tutor to the crown prince, established the version later known as the Zhang Hou Lun 張侯論, a collation primarily based on the Lu Lun with references to the Qi Lun, and added a zhangju 章句 (chapter and verse) commentary. ${ }^{6}$ Bao Xian 包咸 (fl. 10) and other subsequent imperial tutors based themselves on the textual synthesis established by Zhang $\mathrm{Yu}$ which was originally compiled as teaching material for the later emperor Cheng 成 (r. 33-7 BCE). ${ }^{7}$ Although $\mathrm{He}$ Yan does not mention it as such, Zhang's collated version was certainly also consulted by Zheng Xuan; it served as main base text for the jinwen stelae version of 175, and soon established itself as the most prestigious version among Han scholars. Further to Zheng Xuan's efforts, the Lunyu jijie compiled under the main editorship of He Yan is often described as another essential attempt to establish a representative main text (jingwen 經文) of the Lunyu. ${ }^{8}$ From the Lunyu jijie onwards the main text of the Lunyu remains relatively stable. Nevertheless, the bamboo strip manuscript fragments unearthed in 1973 in Dingzhou 定州, the bamboo strip fragments from the former Lelang (Korean: Nangnang) 樂浪 commandery and excavated in 1990, manuscript fragments discovered in Dunhuang and other areas (mainly dating back to the Tang) as well as the stelae versions (from Han to Song) attest to the coexistence of divergent textual traditions and to a variety of lines of transmissions of the Lunyu up to the early Song period. ${ }^{9}$ Some of these textual divergences

For such a reconstruction attempt see Ma Guohan's collection of fragments Yuhan shanfang jiyishu, vol. 3, 1618-1637 (Gu Lun) and 1638-1642 (Qi Lun).

5 See Lunyu jijie, xu, 1a. For collation work on the manuscript fragments of Zheng Xuan's commentary see Wang Su's Tang xieben Lunyu Zheng shi zhu ji qi yanjiu and Chen Jinmu's Tang xieben Lunyu Zheng shi zhu yanjiu. For more general remarks on the Zheng Xuan commentary see Makeham 1997.

6 On Zhang Yu see Han shu 81.3347-3350.

7 On Bao Xian see Han shu 79B.2570; some of his glosses are found in the Lunyu jijie. A reconstruction of the Bao shi zhangju 包氏章句 from quotes is included in Yuhan shanfang jiyishu, vol. 3, 1682-1697; two additional fragments are found in Wang Renjun's Yuhan shanfang jiyishu xubian, 67. Other commentators include a certain "Mister Zhou", or Zhou shi 周氏, of whom we have no further information. Some of his glosses are transmitted in the Lunyu jijie, and fragments of his commentary can be found in Yuhan shanfang jiyishu, vol. 3, 1697ff. On the Lunyu as educational material for princes see also the remarks in Csikszentmihalyi 2002.

8 For collation work on manuscript fragments of the Lunyu jijie from Dunhuang see Li Fang's Dunhuang Lunyu jijie jiaozheng. For a summary on relevant issues regarding this commentary see Makeham 1999.

9 The Dingzhou fragments cover less than half the text of the received Lunyu. Unfortunately reproductions of its actual bamboo slips remain unpublished and the text is only available in transcription (shiwen 釋文) with some rudimentary collation notes; see Dingzhou Hanmu zhujian Lunyu. On the so-called Pyongyang bamboo strip fragments (39 intact slips and 70 fragmentary pieces) which carry parts of only two chapters of the received Lunyu, see Lee Song-si, Yoon Yong-gu and Kim Kyong-ho 2009, and some of the articles in Kim Kyong-ho and Lee Young-ho 2012. I am indebted to Dr. Jo Jungeun 趙貞恩 of Seoul University for taking me through the Korean material. See also Jeon Deog-jae 2012, and Lee 
have an impact on available and possible interpretations of particular passages and are thus crucial for the study of the effective history of the Lunyu.

The bamboo strips from Dingzhou are the earliest surviving textual evidence of utterances of Confucius. They date back to about one generation after Sima Qian and provide us with a textual witness that comes fairly close to the lifetime of the court scribe who made ample reference to records of the utterances of Confucius. ${ }^{10}$ One of the terms used by Sima Qian to name this textual body is Kong shi shu 孔氏 書. ${ }^{11}$ Another expression used in the Shi$j i$ and suspected to refer to a defined written corpus recording utterances of Confucius is Kong shi guwen 孔氏古文. ${ }^{12}$ Some take this taxing expression as synonymous with the title Lunyu, Wang Guowei 王國維 (1877-1927) understands it as a reference to written records transmitted by Confucius and written in old script, and others read it as a more general term covering the entire body of old text material allegedly recovered from the former residence of Confucius. ${ }^{13}$ In the entire Shiji there is only one single occurrence of the expression lun yu / Lunyu 論語 which appears towards the very end of Sima Qian's collective biography of the disciples of Confucius. Most readers tend to perceive it as a book title:

則論言弟子籍, 出孔氏古文近是。余以弟子名姓文字悉取論語弟子問并次為篇。

The Ti-tzu-chi 弟子籍 (Register of Disciples) came from the ancient writings of Confucius' household; it is close to the truth. I took the names of the disciples, then gathered all the records concerning them from among the questions posed by the disciples in the Analects and arranged the information in one chapter. ${ }^{14}$

Sima Qian's narrative on the disciples of Confucius as well as his sketch of the life of Master Kong are the two chapters of the Shiji that exhibit by far the largest number of references to the utterances of Confucius. Textual parallels, quotes from and references to this source confirm that Sima Qian had indeed access to a body of utterances of Confucius that was most likely in some written form. ${ }^{15}$ His quotes from this body, which was at least in part close to that which became known under the title Lunyu, are mainly attributed to Confucius via formulae such as Kongzi yue 孔子曰, Zhongni yue 仲尼曰 and the like,

Song-si, Yoon Yong-gu and Kim Kyong-ho 2011. For a summary on the Dingzhou and the Pyongyang fragments see also van Els 2015 (forthcoming).

10 The Dingzhou mss fragments date from around 55 BCE; the Pyongyang mss fragments date from 45 BCE.

11 See Shiji 47.1947.

12 See Shiji 67.2226.

13 For the reading of this term as a reference to the Lunyu see for example Wang Liqi, Shiji zhuyi, vol. 3, 1678. For Wang Guowei's interpretation see Wang Shumin, Shiji jiaozheng, vol. 7, 2163. For an example of the third reading see Shiji 67.2226 where lunyu/Lunyu is marked as a book title by the editors of the Zhonghua edition.

14 Shiji 67.2226. Translation from Nienhauser 1994, 84. Cf. Csikszentmihalyi 2004, 29.

15 With regard to the quantity of records about his statements and events in the life of Confucius, Wang Chong 王充 (27 - c. 100) in Lunheng 論衡 speaks of “some dozens to a hundred pian” (數十百篇); see Lunheng zhushi, 1598. For some of the titles that Wang Chong may have had in mind here, such as Sanchao ji 三朝記, Zhongni xianju 仲尼閑居, Kongzi Yan ju 孔子燕居 etc., see Sun Shiyang 1933. 
including even shengren yue 聖人日. ${ }^{16}$ This mode of referencing source material stands in a widely attested tradition. The Mengzi 孟子 for instance where none of the quotes from or parallels with utterances of Confucius is referred to by the title Lunyu also makes frequent use of such formulae. ${ }^{17}$ Other sources that are closer to the time of Sima Qian and still attest to this practice include texts such as the $X i n Y u$ 新語, attributed to Lu Jia 陸賈 (240-170 BCE), a text which Sima Qian definitely had seen, and the Xin shu 新書 which is traditionally attributed to Jia Yi 賈誼 (201-169 BCE). ${ }^{18}$

In addition to utterances transmitted in the Lunyu, chapter 47 of the Shiji, the "Hereditary House of Confucius", draws largely on information from sources such as the Liji 禮記, Zuo zhuan 左傳 and Guoyu 國語. ${ }^{19}$ Similarly chapter 67 , the memoir on his disciples, builds on a number of other sources including the Zhongni dizi mulu 仲尼弟子目錄. ${ }^{20}$ The perhaps most prominent source, however, is material later compiled into the Kongzi jiayu 孔子家語, much of which is also attested in parallels transmitted in other pre-Han and Han compilations. ${ }^{21}$ With Sima Qian's sources in mind, one may suggest the following reading of the passage above which would leave us with no direct reference to the title Lunyu in the Shiji:

則論言弟子籍, 出孔氏古文近是。余以弟子名姓文字悉取論語弟子問并次為篇。 Then, the discussions [lun 論] and words [yan 言] in the Register of Disciples come from the ancient writings of Confucius' household and are close to the truth. I took the names of the disciples, gathered all the records concerning them from among

16 For the use of those formulae due to the lack of the existence of a book titled Lunyu see also Takeuchi Yoshio 1939. For the use of the formula Shengren yue see Shiji 79.422. Whether the term shengren in Shiji 79.2422 refers to a particular sage or an anonymous sage remains unclear.

17 It is worth noting here that only eight of the twenty-nine references to utterances of Confucius in the Mencius are actually attested in the received version of the Lunyu which may be taken as an indication of a corpus of utterances of Confucius that was, at the time, much larger than the received versions of the Lunyu would suggest. On the Lunyu parallels in the Mencius see Honda Shigeyuki 本田成之 1927, 173, and Honda Shigeyuki 1935, 131.

18 For Sima Qian's access to the Xin Yu see Shiji 97.2705. In this context some also make reference to the Han Shi wai zhuan 韓詩外傳 (attributed to Han Ying 韓嬰, c. 200-130 BCE) which, in view of some of the issues involved in this case, shall be disregarded here temporarily; see the remarks in Makeham 1996, 12. On Sima Qian seeing the $X$ in Yu see Shiji 97.2705.

19 Much has been written about Sima Qian's sources. A locus classicus is still Chavannes 1895, "Introduction". Cf. also Karlgren 1970, esp. 297 and He Zhihua 2010, 2. For the wider context see Jin Dejian 1963.

20 The Zhongni dizi mulu (1 scroll) is attributed to Zheng Xuan; as it is no longer listed in the bibliography of the Song shi, it was presumably lost in the mid-fourteenth century around 1343-1345. A reconstructed version is found in Yuhan shanfang jiyishu, vol. 3, 1739f. For this material being referred to in the Suoyin commentary on the Shiji, see Cheng Jinzao 1998, 138f.

21 Even if one were to trust Wang Su's 王䛓 (195-256) account on how this compilation became more widely available, it remains questionable whether the Kongzi jiayu, which allegedly derives from family lore of the Kong clan, was available to Sima Qian in any form or shape that resembles the received version. However, with regard to textual parallels between the Shiji and the compilation now known as Kongzi jiayu, the traditional commentaries on the Shiji as well as the notes by Takikawa Kametarō, first published in 1934, provide ample pointers. Cf. Cheng Jinzao 1998, 131-138. 
the questions posed in discussions [lun 論] with and speeches [yu 語] to disciples, and arranged the information in one chapter. ${ }^{22}$

This prompts the questions as to when the term Lunyu was established as the title of a book, an issue that is disputed since the Han. Some relate it to the first generation of disciples of Confucius, some to Kong Anguo or one of his pupils, a certain Fu Qing 扶卿 from the state of $\mathrm{Lu}^{23}$ Some believe it to be established during the Han, probably not before the reign of emperor Wen 文 (r. 180-157 BCE), most likely under emperors Wen or Jing (r. 157-141 $\mathrm{BCE}) .{ }^{24}$ Wang Chong describes the title Lunyu as being established as late as during the reign of emperor $\mathrm{Wu}$ 武 (r. 141-87 BCE) which, by and large, coincides with the lifetime of Sima Qian. ${ }^{25}$ Some see the versions taught in Qi and Lu as emerging during the Han, and regard these versions as jinwen transcriptions that essentially derive from the Gu Lun. ${ }^{26}$ As for the title of the textual body being received as Lunyu, one may argue that the term Lunyu came into existence as a book title around the time when Sima Qian was born. ${ }^{27}$ Sima Qian's own view on this issue is not documented. But with the Dingzhou and the Pyongyang corpora being copied on to bamboo strips after Sima Qian's lifetime and apparently not carrying the title Lunyu, a reading of lun yu in the Shiji as "discussions [lun] and speeches $[y u]$ " would seem an available and indeed attractive reading option. ${ }^{28}$

As even the most fundamental information on the body of records on the utterances of Confucius available to Sima Qian is uncertain, and since the oral transmission of relevant records and their interpretation up to the court scribe's lifetime seems irretrievably lost, a

22 Shiji 67.2226. The parallel 論言弟子籍 and 論語弟子問 suggests that Sima Qian may have been talking about two titles, a Diziji (Register of Disciples) and a Diziwen (Questions of Disciples), both of which reportedly transmitted material regarding the discussions between the Master and his disciples. Alternatively, we may read this passage as indicated in the translation above. In any case, the parallel structure of lun yan 論言 (discussions and words) and lun yu 論語 (discussions and speeches) can be taken as an argument against reading lun $y u$ as a reference to the book title Lunyu in this passage.

23 The attribution of the Lunyu to the first generation of disciples of Confucius, namely Zhonggong 仲弓, Ziyou 子游 and Zixia 子夏, goes back to Zheng Xuan who is frequently quoted on this matter; see for example the Zheng Xuan Lunyu xu yiwen 鄭玄論語序逸文 which is attached to Lunyu zhengyi, 431ff, esp. 431. See also the discussion in Lunheng jiaoshi, 1133. Fu Qing is also known as Fu Xian 扶先 which is taken as an alternate name by some, others read it in the sense of "Mr Fu".

24 See the discussion in Zhao Zhenxin 1961; see also Zhao Zhenxin 1936.

25 See Lunheng zhushi, 1598. For more references on this see the notes in Lunheng jiaoshi, 1131-1134, in Sishu kaoyi, zongkao 9.2b [39], and in the commentary on He Yan's preface to the Lunyu in Lunyu zhengyi, 419-430.

26 On the relation between these three traditions see Takeuchi Yoshio 1939, 69.

27 See also Makeham 1996, 1. In case the title Lunyu was already established as the title of the material recording utterances of Confucius at the time of Sima Qian, an inquiry into the reasons why Sima Qian may have decided to not use this title in the Shiji becomes indispensible.

28 As is the case for the Dingzhou material, there is no indication of the title Lunyu being used for the text fragments found at the former Lelang commandery. Note also that whereas the Dingzhou fragments show a textual sequence similar to that of the received Lunyu, the fragments from the two chapters on the Korean strips exhibit a rather different textual arrangement. 
close reading of the received Lunyu and its textual parallels in the Shiji may provide us with some preliminary glimpses regarding the inter-textual relation of these two sources. ${ }^{29} \mathrm{In}$ this paper I shall thus venture to briefly explore examples of textual and interpretative divergences in the light of other textual witnesses that seem relevant for this inquiry. ${ }^{30}$

Orthography and lexicon: To start with, I shall briefly discuss instances of textual divergences that are of a primarily orthographic nature.

Lunyu 3.8: In a quote from Shijing the passage mei mu pan xi appears in received versions of the Lunyu as 美目盼兮, a writing confirmed in the quote from the Shijing 詩經 by Xu Shen 許慎 (c. 55 - c. 149) in his Shuowen jiezi 說文解字 and also by Lu Deming 陸德明 (556-627) in the Jingdian shiwen 經典釋文. ${ }^{31}$ The Shijing redaction in the Thirteen Classics transcribes the word 盼 as 盻 which, according to the old gloss, stands for "the black and white [of the eye] being well defined" ${ }^{32}$ The verse mei mu pan $x i$ 美目盼/盻兮 is thus read as "beautiful eyes, black and white well defined". However, with regard to the parallel in the Shiji the textual tradition is split: some have 美目盼兮, others write 美目盻兮 ${ }^{33}$ Regardless of this orthographic divergence the commentaries in the Shiji redactions share a reference to the gloss by Ma Rong which aims at an interpretation distinctly different from that in the Shijing corpus and leads to a reading such as "the beautiful eyes flashing". ${ }^{34}$ Though some described 盻 as a non-standard variant of 盼 and others treated the two graphs as representing two distinct terms denoting different meanings, the main point in question here is that the gloss attached to the Shijing corpus is at variance with the commentarial tradition of the Lunyu. The readings in the Shiji context favour Ma Rong's gloss which is also transmitted in the Lunyu jijie and has been an integral part of the Lunyu reception ever since. ${ }^{35}$ In the context of the Lunyu, the quote from the Shijing is thus reinterpreted and takes on a new meaning.

Lunyu 5.1: In the passage leixie zhi zhong (in bonds) the expression leixie (rope [used to bind a criminal or prisoner]), which appears as leixie 縲紲 in Shiji and as 累紲 in Sima Qian's biography in the Han shu, is transcribed as 縲絏 in the received versions of the

29 The important function of the oral transmission of the utterances of Confucius and their interpretations has already been emphasised by Huang Kan 皇㑆 (488-545) in his preface to his subcommentary on the Lunyu jïie; see Lunyu yishu, xu, 3b. There are however some doubts regarding the authenticity of this preface; for a recent discussion see Benjamin A. Elman 2009.

30 For the purpose of this article I shall primarily focus on passages from the first ten books (pian) of the Lunyu.

31 See Shuowen jiezi zhu 4A.3a [130] and Jingdian shiwen 24.3a [1354]: 美目盼兮. For further references on the graphic variations see Ruan Yuan's collation notes to the received Shijing text in Mao Shi zhengyi 3B.24a [133].

32 Mao Shi zhengyi 3B.17a [130] has 美目盻兮. The gloss reads 盻白黑分.

33 Shiji 67.2202 and Shiki Kaichū kōshō 67.28 [8884] have 盼. The Duanjuben redaction Shiji 67.12a [870] and a number of others have 盻.

34 Translation from Nienhauser 1994, 74. Ma Rong's gloss reads 盻 as 動目貌.

35 See Lunyu jijie 2.2a. 
Lunyu. ${ }^{36}$ Shiji seems internally (fairly) consistent and has leixie zhi zhong 縲紲之中 in its quote from the utterances of Confucius. ${ }^{37}$ This orthography is also transmitted in the Lunyu yish $u$ as well as a number of manuscripts up to the stelae of 1131 and $1143 .^{38}$ It appears the graph 絈 can be regarded as a more recent variant that became widely used in this

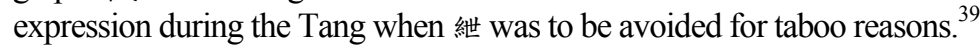

Lunyu 5.6: The orthography of diao as 彫 in the name of the pupil Qidiao Kai 漆彫開 as encountered in Shiji represents an older layer than the orthography transmitted in the perhaps most dominant later tradition of the Lunyu where we read 漆雕開. ${ }^{40}$ The wording found in Shiji is also transmitted in Lunyu jijie, Lunyu yishu and Lunyu zhushu, in Tang manuscripts as well as in the Tang (837) and Song stelae. ${ }^{41}$ Lu Deming gives 调 as a graphic variant; Ruan Yuan takes 彫 as the "proper graph" (zheng zi 正字). ${ }^{42}$ Whatever the orthographic variant in the textual transmission, the interpretation here and in Lunyu 5.10, where the same orthographic instability can be observed, remains stable. ${ }^{43}$

Lunyu 7.31: The name of Wuma Qi, one of the disciples of Confucius, appears as 巫馬期 in current versions of the Lunyu and the Han shu. ${ }^{44}$ Shiji has it as 巫馬旗, a written form also found in Lü shi Chunqiu 吕氏春秋. ${ }^{45}$ It has been argued that $q i$ stands as a loan graph for 旗, a usage that does, however, only come into practice at a later stage. And as Zhai Hao 翟影 (1736-1788) pointed out there are good reasons for considering 旗 the more appropriate graph in view of traditional naming practices and the customarily intertwined relation between alternate names. ${ }^{46}$ As 期 does not seem to be attested as a phonetic loan for 旗 in

36 See Shiji 62.2135, Shiji 83.2468, Han shu 62.2733, Lunyu zhushu 5.1a [41].

37 See Shiji 67.2208 .

38 For further information regarding the graphic representation of the word leixie in various textual transmissions of the Lunyu and beyond see Ruan Yuan's collation notes in Lunyu zhushu 5.1a [47].

39 See Jingdian shiwen 24.5a [1357], the collation notes in Lunyu zhushu 5.1a [47] and the notes in Dunhuang Lunyu jijie jiaozheng, 169.

40 See Shiji 67.2213. Sishu jizhu 四書集註, 80, has 雕. Lunyu zhushu 5.3a [42] has 彫. Note that for taboo reasons some Han sources substitute qi 啟 which was the personal name of Liu Qi 劉啟 (188-141), emperor Jing 景, by the synonym kai 開. Zhang Wenhu $(1977,506)$ indicates a fairly consistent orthography within the text transmission of the Shiji and lists only one redaction that shows the graphic variant 雕 in the name Qidiao Kai.

41 See the Lunyu jijie mss fragment P 3643, Lunyu yishu 3.4a. The Turfan 363 mss fragment also has 染彫 $\square$.

42 See Jingdian shiwen 24.5a [1357], Ruan's notes in Lunyu zhushu 5.2a [47] and Dunhuang Lunyu jijie jiaozheng, 175.

43 The orthographic issues regarding 彫 and 雕 also relate to the phrase 朽木不可彫/雕也 in Lunyu 5.10, the quote of which is printed as 朽木不可雕也 in Shiji 67.2195, Shiji (Duanjuben), 67.6b [867] and Shiki Kaichū kōshō 67.16 [881]. However, Jingdian shiwen 24.5b [1358] glosses 彫, not 雕.

44 See Lunyu jïie 4.5b, Lunyu zhushu 7.9b [64] and 7.10a [64]. Ruan Yuan (Lunyu zhushu 7.6b [68], "Jiaokan ji") and Li Fang $(1998,271)$ attest to a stable transmission of the Lunyu in this case. Han shu 20.926, Han shu buzhu 20.73a [351] as well as Qian Han shu, 330, have 巫馬期.

45 See Shiji 67.2218 and Lü shi Chunqiu 18.21a [132]. Note that the orthography of this name in the latter is not internally coherent for Lü shi Chunqiu, 21.4a-4b [155] has 巫馬期.

46 See Sishu kaoyi, tiaokao 9.12a [217]. With Ziqi 子旗 as his courtesy name (zi 字) in Shiji 67.2218, Wuma Qi's given name (ming 名) is transmitted as Shi 施, the meaning of which is explained by Xu Shen in 
pre-Han literature, one may argue Sima Qian adhered to a textual tradition that was later superseded.

Whereas some orthographic differences have no or little impact on exegetical matters, the way in which orthographic divergences are perceived and conceptualised does, in some cases, lead to divergent readings. One such case is found in a parallel with Lunyu 7.17. The phrase jia wo shu nian appears as 假我數年 in Shiji as well as in a quote attributed to Confucius in Fengsu tongyi 風俗通義 (c. 195). ${ }^{47}$ However, the lines of textual transmissions of the Lunyu attest rather consistently to an alternate wording of this phrase as 加我數年. ${ }^{48}$ Given that jia 加 (to add) and jia 假 (if) may function as phonetic loans and can thus be used indiscriminately, some interpret 加 in the sense of 假, the former being also suspected of deriving from a slip of brush due to phonetic similarity. ${ }^{49}$ But where the exegete decides to take them as two distinct terms, divergent interpretative trajectories become available for further exploration. Readings such as “If I had few more years (假我數年)" stand against “Give me few more years” (加我數年). ${ }^{50}$ Depending also on how the remaining part of Lunyu 7.17 is interpreted, the different perceptions of the studies conducted by Confucius that feature in the exegetical traditions of the Lunyu are informed by and emerge from the way in which this textual discrepancy is negotiated.

In a number of parallels we observe lexical alterations. One such case is found in the phrase that appears as Zizhang wen gan lu 子張問千祿 (Zizhang inquired about [how to] pursue a salaried position) in Shiji and as Zizhang xue gan lu 子張學干祿 (Zizhang studied [how to] pursue a salaried position) in Lunyu $2.18 .^{51}$ In this case the textual transmission of the Lunyu is rather uniform. ${ }^{52}$ Liu Baonan 劉寶楠 (1791-1855) suspects the divergence to be caused by the Gu Lun showing the verb wen 問 whereas the Lu Lun exhibited xue 學 instead, a hypothesis that derives from assumptions regarding Sima Qian's affinity with the guwen tradition. ${ }^{53}$ With the actual textual evidence long lost verification or falsification based on undisputable textual witnesses was already impossible for Liu Baonan. ${ }^{54}$ In case

reference to qi 旗; see Shuowen jiezi zhu 7A.19a [311]; in his commentary Duan Yucai makes explicit reference to the names of Wuma Ziqi. Zhang Wenhu $(1977,507)$ records two redactions of the Shiji in which his courtesy name Ziqi appears as 子祺, an orthographic variant of 子旗 most likely to be caused by a slip of the brush.

47 See Shiji 47.1937. Fengsu tongyi 7.11b [55] has 孔子曰: 假我數年乎.

48 See for example P 2510 and Stein mss 800, Lunyu jïie 4.3b, Lunyu yishu 4.10a, Lunyu zhushu 7.6a [62]. Cf. also the references in Dunhuang Lunyu jijie jiaozheng, 251, on manuscripts and other textual witnesses that carry the wording 加我數年.

49 See for example Sishu jizhu, 99. Zhu Xi glosses: 加作假 [...]蓋加假聲相近而誤讀.

50 Depending on how jia 假 is perceived, the two readings can, of course, have quite some overlap. The juxtaposition above follows the dominant explanatory trajectories attested in the commentarial literature on this passage.

51 See Shiji 67.2204 and Lunyu zhushu 2.6a [18].

52 Lunyu zhushu 2.4a [22] suggests stable transmission.

53 Lunyu zhengyi, 34.

54 It remains somewhat unclear when exactly the Gu Lun ceased to exist. According to Wang Chong it was transcribed into clerical script during the reign of emperor Xuan 宣 (r.74-48); see Lunheng jiaoshi, 1133. Takeuchi Yoshi understands the Qi Lun and Lu Lun as copies of the Gu Lun in clerical script; see 
his informed guess was indeed correct, one might argue that Sima Qian followed the guwen tradition where subsequent collators and exegetes considered the jinwen text a better reading. Rather than relying on conjecture, readers more doubtful about guwen/jinwen issues may well prefer to open up alternate routes of inquiry in dealing with the divergent wordings in this phrase.

At first glance textual amendments caused by taboo conventions seem straightforward. Nevertheless we observe considerable internal inconsistencies in the Shiji as well as inconsistencies on the intertextual level where even graphs such as 邦, which presumably would be altered and substituted by the synonym guo 國 in Han sources, are not avoided or altered on some occasions. ${ }^{55}$ One such case occurs in the phrase zai bang wu yuan 在邦無 怨 (In the state there is no resentment), parallels of which appear in identical wording in Shiji and Lunyu. ${ }^{56}$ It has previously been suggested that the failure to comply with taboo rules in this passage derives from Sima Qian following the $L u$ Lun, which reportedly showed this reading, a postulation that can only be described as disputable on a number of different levels. ${ }^{57}$ Lunyu 12.2 is not transmitted in the Dingzhou corpus, the Pyongyang slips write 在邦無怨. ${ }^{58}$ Other available source texts derive from copies which may already have been (and often are) cleansed of textual amendments caused by Han taboo conventions. ${ }^{59}$ As can be seen from the wording of the phrase bang you dao 邦有道 ("[When] the state has the Way") in Lunyu 5.2 as attested in fragmentary copies of Zheng Xuan's version and of the Lunyu jijie, these late medieval manuscript copies of this passage bear no traces of Han taboo conventions. ${ }^{60}$ Further to this, it seems worth noting that whereas the Lunyu transmission is stable in this case as far as extant witnesses are concerned, parallels with the phrase bang you dao appear in the Shiji as guo you dao 國有 道 ("[When] the state has the Way"). ${ }^{61}$ The question as to why Sima Qian presumably changed the wording on some occasions (parallels with Lunyu 5.2) but did not implement taboo roles on another (parallel with Lunyu 12.2) thus remains open to discussion. It seems preferable to develop inquiries into this issue from the angle of the editorial history of the Shiji rather than via unverifiable conjectures regarding Sima Qian's source material.

Takeuchi Yoshio 1939, 69, and Makeham 1996, 20.

55 For a discussion of issues regarding the observation of taboo rules in the Shiji see Pan Mingii 2009.

56 See Shiji 67.2190 and Lunyu zhushu 12.1b [106].

57 For further details and source references see Pan Mingji 2009, 41f.

58 In the Pyongyang fragments the first two phrases of the Master's response transmitted as Lunyu 12.2 appear on slip 7, the second part of his answer is copied on to slip 23; see Lee Song-si, Yoon Yong-gu and Kim Kyong-ho 2009, 144, 148, 187 and 190f.

59 Lunyu zhushu 12.1a [111] contains no reference to alternate wordings in the redactions consulted by Ruan Yuan and thereby suggest a stable transmission.

60 For Lunyu 5.2 see Lunyu zhushu 5.1b [41]. The lack of references to textual variants in Ruan Yuan's collation notes attests to a uniform transmission; see Lunyu zhushu 5.1a [47]. For mss evidence see the copy of Zheng Xuan's version from Turfan (Stein mss 363) and the Lunyu jijie mss fragment copy $\mathrm{P}$ 3643. Dunhuang Lunyu jijie jiaozheng, 170, lists only one variant in Stein mss 7002 which is however of purely orthographic nature.

61 See the occurrences in Shiji 62.2134, 67.2207, 67.2209 and 79.2422. 
Some lexical amendments in the Shiji are caused by translation of archaisms, a mode of explaining archaisms through modern or more accessible diction. The gloss to a quote from the Shujing 書經 in the main text of the Mengzi (3B.9) is perhaps one of the most famous examples of a Zhanguo-text responding to the needs of his audience by translating an archaic expression into a more widely understood term. ${ }^{62}$ With some of the expressions used in old texts becoming increasingly obscure and difficult to understand during the Han, the frequency with which archaisms were re-phrased in the Shiji attests to this technique being used by Sima Qian on a regular basis. ${ }^{63}$

With regard to grammatical function words the extant textual witnesses testify to considerable instabilities in the transmission of the Lunyu up to the beginning of the Song. Some of these textual variations attested in manuscript copies relate to scribal practices and manuscript culture. Others, like the discrepancies regarding function words between the Lunyu jijie and Huang Kan's 皇㑆 (488-545) Lunyu yishu 論語義疏, reflect textual divergences in different lines of transmission of the main text of the Lunyu. With the appropriate caveats in mind, it is in this context that parallels between the Shiji and the Lunyu provide indications of the linguistic shift between the Zhou and Han periods and its impact on the transmission of the Lunyu.

In phrases like Zhou jian er dai 周監二代 ("[The] Zhou looked back to the two dynasties [i.e. Xia and Shang]") we observe parallels in which the Shiji omits prepositions such as yu 於. ${ }^{64}$ Lunyu 3.14 has the wording as 周監於二代 which is already attested in the Dingzhou corpus and shows a stable transmission. ${ }^{65}$

Another notoriously unstable part of the textual transmission are sentence finals. The current text of the Lunyu for instance shows the final ye in the sentence bu ke de er wen ye 不可得而聞也 (“can not be obtained and heard”) in Lunyu 5.13. ${ }^{66}$ One of the Tang manuscript copies of the Zheng Xuan version contracts the phrase ke de er wen ye 可得而 聞也 (“can be obtained and heard") to ke de er wen 可得聞 (“can be heard") and drops all final particles at the end of Lunyu 5.13 where it has: 不可得而文(聞). ${ }^{67}$ At the end of this passage a number of Lunyu redactions have an additional yi 已 and write 不可得而聞也 已. ${ }^{68}$ The Lunyu yishu and others extend the final phrase to 不可得而聞也已矣 which Ruan Yuan deems to be the most appropriate wording. ${ }^{69}$ The parallel in the Shiji reads:

62 See Mengzi zhushu 6B.3b [117]: 書曰: 洚水警余。洚水者, 洪水。

63 For examples in the wider context see Karlgren 1970.

64 Shiji 47.1936.

65 See Lunyu zhushu 3.8a [28] and Dingzhou Hanmu zhujian Lunyu, 17. This wording is also attested in mss fragments, cf. for example Stein mss 363 and P 2677. With regard to this phrase in Lunyu 3.14 Ruan Yuan records no textual variations; see Lunyu zhushu 4.3b-4a [33-34]. Although the mss copies show minor orthographic divergences, the use of the preposition is however attested consistently; see Dunhuang Lunyu jijie jiaozheng, 112.

66 Lunyu zhushu 5.6a [46] has 子貢日：夫子之文章, 可得而聞也; 夫子之言性與天道, 不可得而聞也。

67 See Stein mss 363: 不可聞. The standard text of this phrase as 可得而聞也 is stable, see for instance the mss fragment of the Lunyu jijie (P 3664), Lunyu yishu 3.10b and Lunyu zhushu 5.6a [46]. Contractions such as the one exhibited in Stein mss 363 are a frequently encountered phenomenon in manuscript culture and do not seem to represent an alternate text tradition.

68 For the wording as 不可得而聞也已 see for instance P 3643. For summaries and further references on the 
夫子言天道與性命, 弗可得聞也已。

[One] can not contrive to hear the Master speaking about the Way of Heaven and [human] nature and fate. ${ }^{70}$

With respect to the finals, Sima Qian's wording is identical to that attested in early copies of the Lunyu jijie. In his Jijie commentary to the Shiji Pei Yin 裴駰 (5th cent.) defines the reading of this passage, especially the terms xing 性 and tiandao 天道, by reference to the Lunyu jijie and does therefore provide no clarification on the term ming 命 in this context. $^{71}$ The expression xing $y u$ tiandao 性與天道 is frequently encountered as an emblematic formula in characterisations of the teachings of Confucius which appears in re-arranged and expanded mode in the Shiji as tiandao $y u$ xingming 天道與性命. ${ }^{72}$ It remains uncertain whether the inverted order and inclusion of ming (fate) among the subjects elaborated on by Confucius reflects Sima Qian's assessment of his teachings, whether this passage allows the reader to speculate about Sima Qian's philosophical background or persuasions, or whether the wording transmitted in the Shiji derives from textual divergences in his source material. ${ }^{73}$

Utilisation of received material: Be it for aesthetic reasons, in order to strengthen the persuasive force of their claim, or indeed with an eye to both these effects, in the advancement of their own arguments traditional authors customarily apply transmitted material in a creative way. By generating resonances to statements attributed to Confucius, Sima Qian routinely employs this technique. An example at hand would be his account of a speech attributed to $\mathrm{Li} \mathrm{Ke}$ 李克 (c. 455-395 BCE). This speech may be perceived as echoing a statement attributed to Confucius and transmitted in Lunyu 2.10, which itself is reminiscent of wording found in the Yi Zhou shu, parts of which date back to the "late 4th or early 3rd century B.C." ${ }^{74}$

textual discrepancies here see the collation notes in Lunyu zhushu 5.5a [49], Dunhuang Lunyu jijie jiaozheng, 187, and Tang xieben Lunyu Zheng shi zhu ji qi yanjiu, 50.

69 See Lunyu yishu 3.10b. The Genji redaction (1864) is a reproduction of Nemoto Sonshi's 根本遜志 (1699-1764) collation work based on the so-called Ashikaga manuscript which dates from between 1521 and 1554. The Lunyu jijie yishu as reproduced in the Zhibuzuzhai congshu 知不足齋丵書, which was widely used by Qing scholars, shows the same wording; see Lunyu jijie yishu, vol. 3, 48. For Ruan Yuan's view see Lunyu zhushu 5.5a [49].

70 Shiji 47.1941. Note also the omission of $e r$ 而 and substitution of the negation $b u$ 不 by $f u$ 弗 in the Shiji parallel. On a summary of the complexities regarding the negations $b u$ and $f u$ see the remarks in Pulleyblank 1995, 103f.

71 See Shiji 47.1941.

72 For instance see Liu Gongmian's postface (houxu) to the Lunyu zhengyi, 434: 非祇謂言性與天道也志。 "[Confucius] did not just talk about [human] nature and the Way of Heaven."

73 The wording of Lunyu 5.13 is not transmitted in the corpora excavated in Dingzhou and Pyongyang.

74 Compare Lunyu 2.10 (視其所以, 觀其所由, 察其所安; 人焉度哉? 人焉廍哉?), Yi Zhou shu 7.3a (考其 所為, 觀其所由) and Shiji 44.1840 (君不察故也。居其所所親, 富視其所與, 達視其所舉, 窮視其所不為, 貧視其所不取, 五者足以定之矣, 何待克哉！). On the Yi zhou shu see Shaughnessy 1993, esp. 230, quote. 
Lunyu 2.19: As Sima Zhen 司馬貞 (c. 656-720) pointed out in his commentary to the Shiji, the narrative of a record of a conversation between Ji Kangzi and Confucius in the Shiji on governance (zheng 政) appears to be a condensed version of the response Confucius reportedly offered when the Duke of Lu enquired about the ways to make his people obedient ( $\min f u$ 民服). ${ }^{75}$ Lunyu 2.19 reads:

哀公問曰：何為則民服。孔子對曰：舉直錯諸枉, 則民服; 舉枉錯諸直, 則民不服。 Duke Ai asked saying: "What action is to be taken to make the people obedient?" Master Kong replied saying: "If one promotes the straight and places them above the crooked, then the people will be obedient. If one promotes the crooked and places them above the straight, then the people will not be obedient." ${ }^{, 76}$

The altered message in the Shiji is linked with a discussion between Confucius and his disciple Zixia recorded in Lunyu 12.22. The Shiji reads:

鲁哀公問政, 對曰：政在選臣。季康子問政, 日：舉直錯諸枉, 則枉者直。

[When] Duke Ai of Lu asked about governance, [Master Kong] answered: "Governance lies in selecting [one's] subordinates." 77 [When] Ji Kangzi asked about governance, [Master Kong] said: "If one promotes the straight and places them above the crooked, then the crooked become straight." $" 78$

What seems noteworthy here is that in Sima Qian's version we observe not only a compressed answer but also a change of interlocutor and an alteration of message. In addition, the Shiji account comes close to what is recorded in Lunyu 12.22 but with a contracted version of the answer being presented by Sima Qian prior to the question. ${ }^{79}$ The utterances transmitted in the Lunyu clearly indicate that responses given by Confucius are highly context-sensitive and therefore depend on his perception of specific characteristics of his interlocutors. The twist to the transmitted material observed in the application of the utterance transmitted in Lunyu 2.19, together with the accounts in Lunyu 12.22, suggests that Sima Qian put into operation a similar ad hominem approach so as to appropriate the material to his ends.

On a number of occasions Sima Qian makes use of the wording attributed to Confucius (and transmitted in the Lunyu) to verbalise his evaluation of historical persons. ${ }^{80}$ The Shiji for instance reports that Confucius ridiculed the Ji's sacrifice to Mount Tai, a reference to a statement transmitted as Lunyu 3.6 that is also taken over in the Han shu 漢書 where Yan

75 See his Suoyin commentary in Shiji 47.1935.

76 Lunyu zhushu 2.6b [18].

77 This is the essence of a statement recorded in Lunyu 12.22 and attributed to Zixia: 子夏日：富哉言乎! 舜有 天下，選於眾，舉臮陶，不仁者遠矣。湯有天下，選於眾，舉伊尹，不仁者遠矣。

78 Shiji 47.1935. The corresponding part in Lunyu 12.22 reads: 子曰：舉直錯諸枉, 能使枉者直。何謂也?

79 Note Pei Yin's (5th cent.) remark in his Jijie commentary in Shiji 47.1935. He takes the view that by condensing the words attributed to Confucius Sima Qian distorted the message and lost factual accuracy.

80 See for example Shiji 42.2779 as a reflection on a passage transmitted in Lunyu 1.10. On Shiji 86.2537 the Suoyin commentary to the Shiji refers to Lunyu 4.2 as a point of reference. Shiji 79.2422 exhibits a partial parallel with Lunyu 7.16 (不義而福且貴; 於我如浮雲) which is prefaced by Shengren yue 聖人日. These examples are mentioned in He Zhihua 2010, $3 \mathrm{ff}$. 
Shigu 顏師古 (581-645) relates it to Lunyu 3.6 through a partial quote in his commentary. ${ }^{81}$ Sima Qian's characterization of Pengzu is highly reminiscent of a passage transmitted in Lunyu 5.25, and as Pei Yin pointed out in his Jijie commentary to the Shiji, Sima Qian's critical evaluation of Lü Buwei has a passage recorded in Lunyu 12.20 as its point of reference. ${ }^{82}$ Though without indication regarding the originator of these statements Sima Qian evokes and refers to statements on Guan Zhong attributed to Confucius by means of textual parallel with Lunyu $3.22 .^{83}$ Another such example is found in chapter 103 of the Shiji where his evaluation of the achievements and performance of Shi Fen 石檑 and others begins with a direct reference to a statement transmitted in Lunyu 4.24:

君子欲訥於言而敏於行。

The accomplished person wishes to be slow to speak but quick to act. ${ }^{84}$

Rather than referring to a named body of transmitted written records, Sima Qian's reference to the originator of the statement simply reads: "Confucius [once] said" (仲尼有 言曰). ${ }^{85}$ From a rhetorical point of view it seems significant that a good deal of applications of utterances of Confucius appears in Sima Qian's appraisals, prefaced by the well-known formula Taishi gong yue 太史公曰 (The Grand Scribe says) that marks his conclusions on narratives of historical figures. This is for instance the case in the concluding statements on Wu Taibo, the beginning of which is a parallel with Lunyu 8.1, prefaced by Kongzi yan 孔 子言. ${ }^{86}$ In his concluding statement on Tian Shu 田叔 for instance Sima Qian echoes the phrase bi wen qi zheng 必聞其政 ([he] always hears about its [i.e. a state's] governance) transmitted in Lunyu 1.10 and prefaces it by the formula Kongzi cheng yue 孔子稱曰. ${ }^{87}$

Omission and addition of words and phrases in textual parallels is another widely observed practice in traditional literature. A considerable number of parallels with the Lunyu can be identified in the Shiji where the latter omits phrases and sentences. Examples include:

Lunyu 3.9: The phrase on the documentation regarding ancient ceremonies being unavailable or inadequate for constituting a suitable basis for discussion is dropped in Shiji. The Lunyu reads:

夏禮吾能言之, 杞不足徵也; 殷禮吾能言之, 宋不足徵也; 文獻不足故也; 足, 則吾能徵之矣。

81 See Shiji 28.1364 and Han shu 25.1199 incl. Yan Shigu's note; cf. He Zhihua 2010, 3f.

82 On Pengzu see Shiji 59:2098 and in Shiji 85.2514 Lü Buwei; cf. He Zhihua 2010, 3, 5.

83 See Shiji 62.2134; cf. He Zhihua 2010, 4.

84 Lunyu zhushu $4.5 \mathrm{~b}$ [38].

85 Shiji 103.2773.

86 See Shiji 31.1475. The Jijie commentary to the Shiji makes explicit reference to Wang Su's explanation of this passage; see Shiji 31.1476; cf. He Zhihua 2010, 3.

87 See Shiji 42.2779 and Lunyu zhushu 1.7b [7]. 
The Xia ceremonies, I can talk about although Qi is not worth taking as evidence. The Yin ceremonies, I can talk about although Song is not worth taking as evidence. This is because the writings and worthies are insufficient. ${ }^{88}$ If they were sufficient, then I could take them as evidence. ${ }^{89}$

The parallel in Shiji omits a crucial part of this passage which is however attested on the Dingzhou bamboo slips and in Tang manuscript fragments of Zheng Xuan's version and of the Lunyu jijie: ${ }^{90}$

夏禮吾能言之, 杞不足徵也。殷禮吾能言之, 宋不足徵也。*足, 則吾能徵之矣。

The Xia ceremonies, I can talk about although Qi is not worth taking as evidence.

The Yin ceremonies, I can talk about although Song is not worth taking as evidence. If they were sufficient, then I could take them as evidence. ${ }^{91}$

The absence of the sentence wenxian bu zu gu ye 文獻不足故也 (“This is because the writings and worthies are insufficient") in the Shiji is not inconspicuous. If Sima Qian's sources contained this phrase and he deliberately omitted it, this could, in view of his work as a historian, suggest that he did not exactly share the assessment of relevant source material put forward by Confucius. Alternatively, one may speculate as to whether the record of the utterances of the Master Kong from which Sima Qian worked actually included this phrase in its version of the statement that is transmitted as Lunyu 3.9. Given the compositional arrangement of Lunyu 3.9, the phrase wenxian bu zu gu ye 文獻不足故也 may well have been an early explanatory commentary that slipped into the main text during the early stages of the compilation of the transmitted versions of the Lunyu. If this phrase was indeed not yet part of the transmitted words of the Master in the version seen by Sima Qian, it must have been integrated into the main text at a stage prior to the version found at Dingzhou. If this is the case, the Shiji represents an early version of Lunyu 3.9, i.e. a version abolished by the later tradition in favour of a more elaborate wording that was perceived as transmitting the assumed meaning of the Master more lucidly.

Lunyu 5.3: In its parallel with Lunyu 5.3 the Shiji drops the "such as he" (ruo ren 若人), a wording otherwise attested consistently in the transmission of the Lunyu including

88 Following the gloss by Zheng Xuan the term wenxian 文獻 is to be taken as "writings and worthies". Zheng Xuan's annotation (see P 3677 and P 2904) which is integrated in Lunyu jijie, Lunyu yishu and Lunyu zhushu reads: 獻猶賢也; see Lunyu zhushu 3.5b [27]. Sishu jizhu, 69, carries the explanation 獻賢 也, thereby following Zheng's gloss but providing, of course, no source reference. An alternate reading of the term wenxian would be "written records".

89 Lunyu zhushu 3.5b [27].

90 For the phrase 文獻不足故也 as attested in the early witnesses see Dingzhou Hanmu zhujian Lunyu, 16, Stein mss 363, P 3677 and P 2904

91 Shiji 47.1936. Note that the Jijie commentary to the Shiji refers to Bao Xian's reading of this passage where zheng 徵 is explained as cheng 成 (complete, perfect), a gloss also transmitted in the Lunyu jijie: 成也。Following Bao Xian's explanation, the passage translated above as "The ruler of Qi is not worth taking as evidence" would read "Qi can not be considered as having reached accomplishment". 
fragments of Zheng Xuan's version from Turfan and the Lunyu jijie manuscript fragment from Dunhuang, as well as in a parallel in the Kongzi jiayu..$^{2}$ The Lunyu reads:

子謂子賤, 君子哉若人! 鲁無君子者, 斯焉取斯?

The Master said of Zijian: An accomplished person indeed is such as he! If Lu had no accomplished person, then where did he get that from? ${ }^{93}$

The parallel in the Shiji reads:

孔子謂子賤君子哉! 鲁無君子, 斯焉取斯?

The Master said of Zijian: An accomplished person indeed! If $\mathrm{Lu}$ had no accomplished person, then where did he get that from? ${ }^{94}$

Lunyu 7.8: In the Lunyu Confucius gives the following account on some of the conditions for receiving his tuition:

不憤不啟, 不悱不發; 舉一隅不以三隅反, 則不復也。

[To those who] are not eager, [I] do not expound [anything]. [To those who] are not urgent, I do not reveal [anything]. If [I] raise one corner and [they] do not come back with three corners, then I do not repeat [myself]. ${ }^{95}$

Sima Qian drops the aspect of the learner bursting to speak (不悱不發). His version reads:

不憤不啟, 舉一隅不以三隅反, 則弗復也。

[To those who] are not eager, [I] do not expound [anything]. If [I] raise one corner and [they] do not come back with three corners, then I do not repeat [myself]. ${ }^{96}$

Examples of Sima Qian making additions to passages from the records of the Master's utterances include a parallel with Lunyu 7.19 which is interpolated with references to another speech, thereby bringing together accounts that are normally seen as unrelated. As far as the textual traditions of the Lunyu are concerned, the transmission of the relevant part of Lunyu 7.19 is stable except for the function words at the end of the sentence. The Lunyu reads: ${ }^{97}$

其為人也, 發憤忘食, 樂以忘憂, 不知老之將至云爾。

He is the type of man who gets so excited that he forgets to eat, so happy that he forgets [his] worries, and is not aware that old age will soon be at hand. ${ }^{98}$

92 This passage is not transmitted in the Dingzhou corpus; for fragments see Stein mss 363 and P 3643. For the parallel see Kongzi jiayu 5.32 which also carries Wang Su's gloss on 若人.

93 Lunyu zhushu 5.1b [41].

94 Shiji 47.2207.

95 Luпyu zhushu 7.3a [61].

96 Shiji 47.1938.

97 With regard to the sentence finals some versions including the Lunyu yishu have ye yun er 也云爾 where the dominant textual traditions have yun er 云爾. P 2510 exhibits the short hand 云尔. The Dingzhou version omits 將 and shows the sentence finals as 云電; see Dingzhou Hanmu zhujian Lunyu, 33.

98 Lunyu zhushu 7.6b [62]. 
The Shiji version merges passages transmitted in Lunyu 7.19 and Lunyu 7.2 (學而不厭, 誨 人不倦) with a slightly altered wording: xue er 學而 (“to learn / study and / but”) of the Lunyu text becomes xue dao 學道 ("to study the Way") in the Shiji: 99

其為人也, 學道不倦, 誨人不厭, 發憤忘食, 樂以忘憂, 不知老之將至云爾。

He is the type of man who studies the Way without becoming tired, teaches people without growing weary, gets so excited that he forgets to eat, so happy that he forgets [his] worries, and is not aware that old age will soon be at hand. ${ }^{100}$

Lunyu 6.9: As Lu Deming and Ruan Yuan 阮元 (1764-1849) pointed out, Zheng Xuan's wording of the final phrase in the sentence ru you fu wo zhe, ze wu bi zai Wen shang yi 如 有復我者, 則吾必在汶上矣 (“[If] someone comes back for me, then I shall certainly be beyond the [river] Wen") drops the words ze wu 則吾. ${ }^{101}$ Exactly the same omission is found in an otherwise perfect parallel with the received Lunyu in Shiji. ${ }^{102}$ One is therefore tempted to suggest the wordings transmitted in the Zheng commentary and in Shiji derive from the same source and preserve a reading that was deemed inferior by later collators of the Lunyu who judged the wording ze wu bu zai Wen shang yi the better option. ${ }^{103}$

Historicising and re-contextualising: The large majority of utterances recorded in the Lunyu are transmitted as isolated statements or short dialogues. It is often the case that hardly any information is provided in terms of his interlocutors or of the circumstances in which those words were situated. Since contextual matters and situatedness play a crucial function in the exegetical process commentators have engaged in the reconstruction of contextual aspects ever since. As his biography of Confucius may be read as a historicising narrative that binds transmitted statements and events to specific situations in the life story of their originator, and given that the earliest extant commentaries on the Lunyu date from periods well after his lifetime, Sima Qian's contextualisation of otherwise isolated utterances are of great significance for the interpretative traditions of the Lunyu.

In some cases the sequence of events recorded in the Shiji coincides with the textual sequence transmitted in the Lunyu. For instance in a case like the utterances transmitted as Lunyu 15.2 and 15.3 one may argue that Sima Qian's historical narrative is developed from the textual arrangement found in the Lunyu. ${ }^{104}$ Undoubtedly such a notion presumes that the records on the utterances of Confucius seen by Sima Qian exhibited the same or at least very similar structure as the text transmitted under the title Lunyu. In view of the

99 Although the phrase 誨人不倦 also appears in Lunyu 7.34, Lunyu 7.2 seems to be the main point of reference here.

100 Shiji 47.1928.

101 See the gloss in Jingdian shiwen, 24.6b [1360] and Ruan Yuan's note in Lunyu zhushu 6.3a [57]. For the main text of the Lunyu see Lunyu zhushu, 6.4a [52]. On the Dingzhou version only a part carrying the wording 我必在汶上矣 survived; see Dingzhou Hanmu zhujian Lunyu, 27.

102 Shiji 67.2189: 如有復我者, 必在汶上矣。

103 Unfortunately no further information is transmitted on the source from which this wording stems.

104 Compare Lunyu 15.2 and Lunyu 15.3 in Lunyu zhushu 15.1b-2a [137] with the account in Shiji 47.1930. 
organization of the text in the fragments from Dingzhou this assumption seems reasonable. The bamboo slips provide fragmentary textual evidence that confirms that the sequence of utterances and overall textual organization of this textual witness from the Han corresponds to the internal organization of the received version of the Lunyu. As for the case of Lunyu 15.2 and Lunyu 15.3, the Dingzhou corpus supports an argument for Sima Qian arranging his narrative according to received records on the utterances of Confucius. ${ }^{105}$

In other cases the actual message of a specific statement may be clouded by the lack of context. This certainly applies to the following passage which is transmitted as Lunyu 7.23 and for which the main text of the Lunyu provides the reader with no context:

\section{天生德於予，桓魋其如予何！}

Heaven has endowed me with virtue, so what will Huan Tui have to do with me? ${ }^{106}$

According to Sima Qian's contextualization, this statement was made after Huan Tui, a military minister in the state of Song who allegedly disliked Confucius and his pupils travelling through his state, reportedly cut down a tree beneath which the Master and his disciples practiced ceremonies in an attempt to kill Confucius. ${ }^{107}$ As for subsequent Lunyu exegetes, Bao Xian provides information on Huan Tui's position in Song and elaborates on the implications of Confucius' mission from heaven. ${ }^{108}$ Zheng Xuan takes over parts of Bao Xian's gloss and explains this mission from heaven as "establishing order". In addition he provides more information on Huan Tui's identity and notes that he strongly disliked ( $j i$ 疾) Confucius and wanted to kill him. ${ }^{109}$ Huang Kan describes Huan Tui as a malicious person who wanted to harm (hai 害) Confucius. He surmises this statement was made in order to put an end to Huan Tui's malevolent intentions and quotes Jiang Xi 江熙 (4th cent.) who perceives this as an allegory on how to deal with malicious mediocre persons (xiaoren 小 人). ${ }^{110}$ As far as can be said from the available material, none of the major early commentators up to Xing Bing's 邢旵 (931-1010) concise Lunyu-reader of 999 mentions the tree that features so prominently in Sima Qian's account. With his reference to and quote from the Shiji in his subcommentary in the Lunyu zhengyi 論語正義, also known as Lunyu zhushu jiejing 論語注疏解經 or Lunyu zhushu 論語注疏, Xing Bing brings the context established by Sima Qian into mainstream Lunyu reception. As for subsequent dominant commentaries and interpretations, Zhu Xi 朱喜 (1130-1200) disregards Sima Qian's version of events in his Lunyu jizhu 論語集註 (1177) whereas Liu Baonan and his son Liu Gongmian 劉恭冕 (1824-1883) integrate the Shiji narrative in their magisterial commentary

105 For the fragments of Lunyu 15.2 and Lunyu 15.3 see Dingzhou Hanmu zhujian Lunyu, 70.

106 Lunyu zhushu 7.7b [63].

107 See Shiji 47.1921. In the Zhuangzi the narrative regarding this attempt on his life is embedded in the formalized lore on mishaps in the life of Confucius. For further observations on the four references to this event in the Zhuangzi see Makeham 1998.

108 See Lunyu jijie 4.4a. Huan Tui is, of course, also mentioned in the Mencius where some information on this person can be obtained.

109 See P 2510. Cf. also Tang xieben Lunyu Zheng shi zhu ji qi yanjiu, 79.

110 See Lunyu yishu, 4.14a. 
of $1866 .^{111}$ This is to say the earlier commentarial traditions of the Lunyu chose to disregard the context established in Sima Qian's narrative whereas more recent reading suggestions are, with one notable exception, shaped by the account of events provided in the Shiji. ${ }^{12}$

\section{$*$}

According to the autobiographical part of his postface (zixu 自序) to the Shiji, Sima Qian reached considerable familiarity with guwen at the tender age of ten $s u i .{ }^{113}$ Given that he studied Kong Anguo's guwen version of the Shangshu 尚書, the assumption that he also studied and followed Kong's tradition of the Gu Lun is widespread. As a result of this line of reasoning we frequently encounter the notion that textual divergences between the recent Lunyu and its parallels in the Shiji derive from textual idiosyncrasies at the very early stages of the transmission of the Lunyu or its predecessors.

Looking at the textual evidence, there clearly is support for the argument that Sima Qian followed variants, be that orthographic or compositional, which became obsolete in the later textual transmission of the Lunyu. It also seems evident that in his references to utterances attributed to Confucius Sima Qian applied a broad repertoire of techniques widely attested in traditional literature. ${ }^{114}$ Nonetheless hardly any of these techniques seems to support a solid case for perceiving the parallels in the Shiji as a reasonably reliable representation of or approximation to the text body that was constituted the Gu Lun, a material that ceased to exist long ago and could no longer be read against parallels provided by the court scribe even by those remarkable Qing scholars who showed such extraordinary dedication to the reconstruction of archaic matters and textual traditions. The examples presented here illustrate the complexities regarding Sima Qian's source material, the questionable classification of parallels in the Shiji along the doubtful lines of three traditions (reconstructed and) established during the Han, the liberties Sima Qian took and the creativity he applied in appropriating and weaving given material into his narrative.

More importantly, where the application of a received text to a specific context is considered to be the primary task of the exegete, the Shiji may be read as an early hermeneutical attempt to contextualise and clarify the transmitted utterances of Master Kong. As the relevant parts of the Shiji take on the function of a commentary, Sima Qian's work constitutes no less than the earliest extant text material that provides interpretation, contextualisation and application of a significant portion of the utterances attributed to Master Kong.

111 See Sishu jizhu, 100, and Lunyu zhengyi, 147. Lunyu yizhu, one of the most widely received modern annotated versions of the Lunyu, also provides the relevant quote from Shiji; see Lunyu yizhu, 72.

112 The reasons why the early commentarial traditions (especially up to He Yan) eclipse this narrative relate, in all probability, to hagiographic issues and, to some extent, also to the simple fact that copies of the Shiji were, for some centuries after Sima Qian's death, by no means easily accessible. On some of the relevant hagiographic aspects, especially the tradition established by the compiler(s) of the Kongzi jiayu, see Hans van Ess 2011. On the problems regarding access to copies of the Shiji see Lü Shihao 2009.

113 See Shiji 130.3293.

114 See also He Zhihua 2010, 1 . 


\section{References}

Chavannes, Édouard (tr.). 1895-1905, 1969. Les Mémoires historiques de Se-ma Ts'ien. [6 vols. Paris: Leroux, 1895-1905, reprint: Maisonneuve, 1967: Tome I-V; Maisonneuve, 1969: Tome VI].

Chen Jinmu 陳金木. 1996. See Tang xieben Lunyu Zheng shi zhu yanjiu.

Cheng, Anne. 1993. “Lun yü’, in Loewe 1993, 313-323.

Cheng Jinzao 程金造. 1998. Shiji suoyin yin shu kaoshi 史記索鿵引書考實. Beijing: Zhonghua [2 vols.].

Csikszentmihalyi, Mark. 2002. "Confucius and the Analects in the Han", in Bryan W. van Norden: Confucius and the Analects. New Essays (Oxford: Oxford University), 134-162.

- 2004. Material Virtue. Ethics and the Body in Early China. Leiden: Brill.

Dingzhou Hanmu zhujian Lunyu 定州漠墓竹簡論語. Beijing: Wenwu, 1997.

Duan Yucai 段玉裁 (1735-1815). See Shuowen jiezi zhu.

Dunhuang “Lunyu jijie” jiaozheng 敦煌《論語集解》校證, ed. by Li Fang 李方. Dunhuang wenxian fenlei lujiao congkan 敦煌文獻分類錄校叢刊. Nanjing: Jiangsu guji, 1998.

Elman, Benjamin A. 2009. "One Classic and Two Classical Traditions: The Recovery and Transmission of a Lost Edition of the Analects", Monumenta Nipponica 64.1, 53-82.

Els, Paul van. 2015, forthcoming. “Confucius' Sayings Entombed: On Two Han Dynasty Bamboo Analects Manuscripts", to be published in Kern, Hunter and Weingarten.

Ess, Hans van. 2011. "Einige Anmerkungen zur Biographie des Konfuzius im Shih-chi und vergleichbaren Stellen im K'ung Tzu chia-yü’', Oriens Extremus 50, 157-180.

Fengsu tongyi 風俗通義, by Ying Shao 應劭 (fl. 189-194). Sibu congkan.

Han shu 漢書, by Ban Gu 班固 (32-92), comm. by Yan Shigu 顔師古 (581-645). Beijing: Zhonghua, 1962 [1987 printing. 12 vols.].

Han shu buzhu 漢書補注, by Ban Gu, comm. by Yan Shigu and Wang Xianqian 王先謙, ed. by Wang Deyi 王德毅 and Xu Qinting 徐芹庭. Ershiwu shi: duanjuben 二十五史: 斷句本. Taipei: Xinwenfeng, 1975 [2 vols.].

He Yan 何晏 (190-249). See Lunyujijie.

He Zhihua [Ho Che Wah] 何志華. 2010. “Shiji quanshi Lunyu kao”史記詮釋論語考, paper presented at the conference “Zhong Ri Han jingxue guoji xueshu yantaohui” 中日韓經學國際學術研討會, Hong Kong, Baptist University.

Honda Shigeyuki 本田成之.1927. Shina Kyōgaku shiron 支那經學史論. Kyōto: Kōbundō.

—. 1935. Zhongguo jingxueshi 中國經學史. Chinese translation of Shina Kyōgaku shiron, ed. by Sun Lianggong 孫很工. Shanghai: Zhonghua [reprint: Taipei: Guting, 1975].

Huang Hui 黄暉. 1935. See Lunheng jiaoshi.

Huang Kan 皇㑆 (488-545). See Lunyu yishu.

Jeon, Deog-jae. 2012. "Materials and trends in the study of ancient Korean wooden slips", Review of Korean Studies 15.1, 167-197.

Jin Dejian 金德見. 1963. Sima Qian suojian shu kao 司馬遷所見書考. Shanghai: Shanghai renmin.

Jingdian shiwen 經典釋文, ed. by Lu Deming 陸德明 (556-627). 3 vols. Shanghai: Shanghai guji, 1985.

Karlgren, Bernhard. 1970. "Sidelights on Si-ma Ts'ien's Language”, Bulletin of the Museum of Far Eastern Antiquities 42, 297-310.

Kern, Martin, Michael J. Hunter, and Oliver Weingarten (eds.). 2015 (forthcoming). The Analects: A Western Han Text? [working title]. 
Kim Kyong-ho 金慶浩 and Lee Young-ho 李映昊 (eds.). 2012. Chiha ŭi Nonŏ, Chisang ŭi Nonŏ 지하 (地下) 의 논어, 지상 (紙上) 의 논어. Tong Asia munmyŏng ch'ongsŏ 동아시아 문명총서, 4. Seoul: Sungkyunkwan University 성균관 대학교.

Kong Yingda 孔穎達 (574-648). See Mao Shi zhengyi.

Kongzi jiayu 孔子家語, comm. by Wang Su 王肃 (195-256). Sibu beiyao.

Lee Song-si 李城市, Yoon Yong-gu 尹龍九 and Kim Kyong-ho. 2009. "P'yŏngyang Chŏngbaekdong 364 hobun ch'ult'o chukkan Nonŏ e taehayŏ” 平壤貞柏洞 364 號垻출토竹簡論語에 대하여, Mokkan kwa muncha 목간과문자 [木簡과 文字] 2009.4, 127-166.

__ Y Yoon Yong-gu and Kim Kyong-ho. 2011. "Pingrang Zhenbodong 364 hao mu chutu zhujian Lunyu” 平壤貞柏洞 364 號墓出土竹簡論語, Chutu wenxian yanjiu 出土文獻研究 10, 174-206.

Li Fang 李方 (ed.). 1998. See Dunhuang Lunyu jijie jiaozheng.

Liu Baonan 劉賽楠 (1791-1855) and Liu Gongmian 劉恭冕 (1824-1883). See Lunyu zhengyi.

Loewe, Michael (ed.). 1993. Early Chinese Texts: A Bibliographical Guide. Berkeley: The Society for the Study of Early China and The Institute of East Asian Studies, University of California.

Lu Deming 陸德明 (556-627). See Jingdian shiwen.

Lü shi Chunqiu 吕氏春秋, comm. by Gao You 高誘 (fl. 205-212). Sibu congkan.

Lü Shihao 吕世浩. 2009. Cong “Shiji” dao “Hanshu”: Zhuanzhe guocheng yu lishi yiyi 從《史記》到 《漢書》一轉折過程與歷史意義. Taipei: Taiwan daxue.

Lunheng jiaoshi 論衡校釋, ed. by Huang Hui 黄暉. 4 vols. Beijing: Shangwu, 1935 [reprint: Taipei: Taiwan Shangwu, 1983. 2 vols.].

Lunheng zhushi 論衡注釋. 4 vols. Beijing: Zhonghua, 1979.

Lunyu yinde: fu biaojiao jingwen 論語引得一附標校經文 / A Concordance to the Analects of Confucius, ed. by Hong Ye [William Hung] 洪業. Sinological Index Series (Supplement no. 16.). Beiping: Harvard-Yenching Institute, 1940 [reprint: Taibei: Chinese Materials and Research Aids Service Center, 1966].

Lunyu jijie 論語集解, comm. by He Yan 何晏 (190-249). Yuan edition [reprint: in Wuqiubeizhai Lunyu jicheng].

Lunyu jijie yishu 論語集解義疏, comm. by He Yan and Huang Kan 皇㑆 (488-545). Zhibuzuzhai congshu.

Lunyu yishu 論語義疏, comm. by Huang Kan. Japanese Genji 元治 ed. from 1864 [reprint: in Wuqiubeizhai Lunyu jicheng].

Lunyu yizhu 論語譯注, ed. by Yang Bojun 楊伯峻 (1909-1992). Beijing: Zhonghua, [1958, ${ }^{2} 1980$ [reprint: 1988].

Lunyu zhengyi 論語正義, comm. by Liu Baonan 劉賽楠 (1791-1855) and Liu Gongmian 劉恭冕 (1824-1883). Zhuzi jicheng.

Lunyu zhushu 論語注疏, comm. by He Yan and Xing Bing 邢昺 (932-1010). Shisan jing zhushu.

Ma Guohan 馬國翰 (1794-1857). 1883. See Yuhan shanfang jiyishu.

Makeham, John: "On the Formation of the Lunyu as a Book", Monumenta Serica 44 (1996), 1-25.

- 1997. "The Earliest Extant Commentary on Lunyu: Lunyu Zheng shi zhu", T'oung Pao 83, 260-299.

—. 1998. "Between Chen and Cai. Zhuangzi and the Analects", in: Roger T. Ames: Wandering at Ease in the Zhuangzi (Albany: State University of New York), 75-100.

—. 1999. "He Yan, Xuanxue and the Editorship of the Lunyu jijie", Early Medieval China 5, 1-35. . 2007. "A New Hermeneutical Approach to Early Chinese Texts", in: Lauren Pfister, ed.: Hermeneutical Thinking in Chinese Philosophy (Book Supplement Series of the Journal of Chinese Philosophy. Malden, MA: Blackwell), 95-108. 
Mao Shi zhengyi 毛詩正義, comm. by Kong Yingda 孔穎達 (574-648). Shisan jing zhushu.

Mengzi zhushu 孟子注疏, comm. by Zhao Qi 趙岐 (d. 201) and Sun Shi 孫爽 (962-1033). Shisan jing zhushu.

Nienhauser, William H. (ed.). 1994. The Grand Scribe's Records, Volume VII: The Memoirs of PreHan China. Bloomington: Indiana University.

Pan Mingji 潘銘基. 2009. “Shiji yu xian Qin liang Han hujian dianji bihui yanjiu” 史記與先秦兩漢互 見典籍避諱研究, Zhongguo wenhua yanjiusuo xuebao 中國文化研究所學報, 49, 35-64.

Pulleyblank, Edwin G. 1995. Outline of Classical Chinese Grammar. Vancouver: University of British Columbia.

Qian Han shu 前漢書, by Ban Gu 班固 (32-92), comm. by Yan Shigu 顏師古 (581-645). Sibu beiyao.

Ruan Yuan 阮元 (1764-1849). See Shisan jing zhushu.

Shaughnessy, Edward L. 1993. “I chou shu”, in Loewe 1993, 229-233.

Shiji 史記, by Sima Qian 司馬遷 (c.145-c. 85 BCE), comm. by Pei Yin 裴駰 (5th cent.), Sima Zhen 司馬貞 (ca. 656-720) und Zhang Shoujie 張守節 (8th cent.) [= Sanjia zhu 三家注]. 10 vols. Beijing: Zhonghua, 1959 [1982 printing].

Shiji 史記, by Sima Qian, with Sanjia zhu 三家注, ed. by Wang Deyi 王德毅 and Xu Qinting 徐芹庭. Ershiwu shi 二十五史 [Duanjuben 斷句本]. 2 vols. Taipei: Xinwenfeng, 1975.

Shiki kaichū kōshō 史記會注考證, by Sima Qian, with Sanjia zhu 三家注, ed. by Takigawa Kametarō 瀧川龜太郎 (1865-1946). Tōkyō: Tōhō bunka gakuin Tōkyō kenkyūjo, 1932-1934 [reprint: with add. paging: Taipei: Zhongxin, 1982].

Shisan jing zhushu: fu jiaokanji 十三經注疏: 附校勘記, ed. by Ruan Yuan 阮元 (1764-1849). Jiangxi: Nanchang fuxue 江西: 南昌府學, 1815-1816 [reprint with add. paging: Taipei: Yiwen, 1971. 8 vols.].

Sibu beiyao 四部備要. Shanghai: Zhonghua, 1920-1933 [reprint: Beijing: Zhonghua, 1989. 100 vols.].

Sibu congkan 四部叢刊. Shanghai: Shangwu, 1919-1936 [reprint: Taipei: Taiwan Shangwu, 1971. 100 vols.].

Sishu kaoyi 四書考異, ed. by Zhai Hao 翟䫝 (1736-1788). Edition from 1769 [reprint in Xuxiu siku quanshu].

Shuowen jiezi zhu 說文解字注, by Xu Shen 許慎 (c. 55 - c. 149), comm. by Duan Yucai 段玉裁 (1735-1815). Shanghai: Shanghai guji, 1981.

Sishu jizhu 四書集註, ed. by Zhu Xi 朱喜(1130-1200). Taipei: Xuehai, 1984.

Sun Shiyang 孫世揚. 1933. “Lunyu kao”論語考, in: Gushi bian 古史辨, vol. 4, ed. by Gu Jiegang 顧頡 剛 (Beiping: Pushe 樸社. reprint: Hong Kong: Taiping, 1962), 89-94.

Takeuchi Yoshio 武內義雄 (1886-1966). 1939. Rongo no kenkyū 論語之研究. Tōkyō: Iwanami [reprint: Takeuchi Yoshio zenshū 武内義雄全書 (10 vols. Tokyo: Kadokawa, [1965-66] 197879), vol. 1].

Takigawa Kametarō 瀧川䣖太郎 (1865-1946). 1932-1934. See Shiki kaichū kōshō.

Tang xieben Lunyu Zheng shi zhu ji qi yanjiu 唐寫本論語鄭氏注及其研究, ed. by Wang Su 王素. Beijing: Wenwu, 1991.

Tang xieben Lunyu Zheng shi zhu yanjiu 唐寫本論語鄭氏注研究, ed. by Chen Jinmu 陳金木. Taipei: Wenjin, 1996 [3 vols.].

Wang Liqi 王利器 (ed.). 1988. Shiji zhuyi 史记注譯. 4 vols. Xi’an: San Qin, 1988.

Wang Renjun 王仁俊 (1866-1912). 1894. See Yuhan shanfang jiyishu xubian.

Wang Shumin 王叔伥. 1982. Shiji jiaozheng 史記橎證. 10 vols. Taipei: Academia Sinica, 1982.

Wang Su 王素. 1991. See Tang xieben Lunyu Zheng shi zhu ji qi yanjiu.

Wang Xianqian 王先謙(1842-1918). See Han shu buzhu. 
Wuqiubeizhai Lunyu jicheng 無求備齋論語集成, ed. by Yan Lingfeng 嚴靃峰 (1903-1999). Taipei: Yiwen, 1966 [30 cases, 308 vols.].

Xing Bing 邢昺 (932-1010). See Lunyu zhushu.

Xu Shen 許慎 (c. 55 - c. 149). See Shuowen jiezi zhu.

Xuxiu Siku quanshu 續修四庫全書. Shanghai: Shanghai guji, 2002 [1300 vols.].

Yang Bojun 楊伯峻 (1909-1992). See Lunyu yizhu.

Yi Zhou shu 逸周書, comm. by Kong Zhao 孔昆, ed. by Lu Wenchao 盧文弨 (1717-1795). Sibu beiyao.

Yuhan shanfang jiyishu 玉函山房輯伙書. Collection of fragments, ed. by Ma Guohan 馬國翰 (1794 1857). Changsha: Langhuan guan 長沙嫏嬛館, 1883 [reprint: Yangzhou: Guangling shushe, 2004. 5 vols].

Yuhan shanfang jiyishu xubian 玉函山房輯佚書續編, ed. by Wang Renjun 王仁俊 (1866-1912). Handwritten ed. dated 1894 [reprint in Yuhan shanfang jiyishu buyi 玉函山房輯佚書補遺 (Taipei: Dahua, 1990), 1-270].

Zhai Hao 翟瀕 (1736-1788). See Sishu kaoyi.

Zhang Wenhu 張文虎 (1808-1885) (ed.). 1977. Jiaokan Shiji jijie suoyin zhengyi zhaji 校刊史記集解 索鿵正義札記. 2 vols. Beijing: Zhonghua [reprint: 2012]

Zhao Zhenxin 趙貞信. 1936. “Lunyu yi ming zhi laili yu qi jieshi”論語一名之來歴與其解釋, Shixue jikan 史學集刊 2,1-40.

Zhao Zhenxin 趙貞信. 1961. “Lunyu jiujing shi shei bianzuan de”論語究竟是誰編纂的, Beijing shifan daxue xuebao (Shehui kexue ban) 北京師範大學學報 (社會科學板) 1961.4, 11-24.

Zhibuzuzhai congshu 知不足齊丵書, ed. by Bao Tingbo 鮑廷博 (1728-1814). Edition from 17761823 [reprint: Beijing: Zhonghua, 1999. 10 vols.].

Zhuzi jicheng 諸子集成, ed. by Guoxue zhenglishe 國學整理社. Beijing: Zhonghua, 1954 [reprint 1993. 8 vols.].

Zhu Weizheng 朱維鋝. 2002. “Lunyu jieji cuoshuo”論語結集脞說, in Zhu Weizheng, Zhongguo jingxueshi shi jiang 中國經學史十講 (Shanghai: Fudan daxue), 97-123.

Zhu Xi 朱喜(1130-1200). See Sishujizhu. 